Vol. 10 (2001): 277-284.

\title{
Blue sticky traps are more efficient for the monitoring of Lygus rugulipennis (Heteroptera, Miridae) than yellow sticky traps
}

Jarmo K. Holopainen

MTT Agrifood Research Finland, Plant Production Research, Plant Protection, FIN-31600 Jokioinen, Finland.

Current address: Department of Ecology and Environmental Science, University of Kuopio, PO Box 1627,

FIN-70211 Kuopio, Finland, e-mail: jarmo.holopainen@uku.fi

Sakari Raiskio

MTT Agrifood Research Finland, Plant Production Research, Plant Protection, FIN-31600 Jokioinen, Finland

Anu Wulff

Department of Ecology and Environmental Science, University of Kuopio, PO Box 1627,

FIN-70211 Kuopio, Finland

Kari Tiilikkala

MTT Agrifood Research Finland, Plant Production Research, Plant Protection, FIN-31600 Jokioinen, Finland

Lygus bugs (Heteroptera, Miridae) are important pests of several crop plants. For the development of an efficient monitoring and forecasting system for Lygus densities, low catches of bugs with yellow sticky traps have been a problem. We determined the spectral reflectance of yellow and blue traps and compared their catches of Lygus spp. during five consecutive growing seasons in carrot fields, with additional data collected from other crop plants. Blue sticky traps caught significantly more omnivorous Lygus rugulipennis (Popp.) than yellow sticky traps in carrot fields. Lygus kalmi (L.) that is a typical species in carrot fields, was equally caught by yellow and blue traps. Our results suggest that blue sticky traps are a convenient method for monitoring of L. rugulipennis especially during the seedling stage of cultivated carrot plants when sweep netting cannot be used. Factors affecting the efficiency of blue sticky traps to capture omnivorous bugs and thrips are discussed.

Key words: Lygus rugulipennis, Lygus kalmi, European tarnished plant bug, omnivory, insect orientation, visual stimuli, trap type, integrated control

\section{Introduction}

In host plant detection by insects visual stimuli play an important role, especially among gener- alist insects which have host plants with variable morphological characteristics. The physical stimulus perceived by the insect is affected by brightness (intensity of reflected light), hue (dominant wavelength of reflected light) and 
Holopainen, J.K. et al. Lygus spp. monitoring with blue sticky traps

saturation (spectral purity of reflected light) (Prokopy and Owen 1983). Relative to other colours, the yellow colour is known to attract many herbivorous insects (e.g. Johnson and Mueller 1988, Kostal and Finch 1996) and therefore yellow water pans and sticky traps are usually used for insect monitoring. In cabbage root flies the preference for yellow traps compared to blue and violet trap was innate even in young flies (Kostal and Finch 1996).

Several species in the genus Lygus have hundreds of host plant species and they are significant pests of many important crop plants (Holopainen and Varis 1991, Young 1986). The most important species in Europe is L. rugulipennis, which is a pest on crop plants as well as forest trees in nurseries (Holopainen 1986) like other Lygus species in Northern America (Schowalter and Stein 1987). The movement of Lygus bugs to the crops from their hibernation sites (Varis 1995) or from other cultivated plants (Fleisher et al. 1988) is easily monitored with sweep net sampling (Varis 1995). However, sweep netting is time-consuming, may harm emerging seedlings and does not catch samples properly from small seedlings, which are often most severely damaged by Lygus spp. (Fye 1984, Holopainen 1986).

For the development of efficient monitoring and forecasting systems of Lygus populations, the low catches of bugs with yellow sticky traps have been a problem. Especially, in organic farming, monitoring of L. rugulipennis is needed for timing different plant protection measures. The use of virgin Lygus female (Slymaker and Tugwell 1984, Holopainen and Rikala 1991) as a bait in yellow sticky traps has increased catching efficiency of yellow sticky traps significantly, but this method is too laborious for routine use. Therefore, we tested attractivity of blue sticky traps for monitoring purposes of L. rugulipennis and other Lygus spp. damaging especially small carrot seedlings.

\section{Material and methods}

\author{
Traps
}

The traps were disposable $190 \mathrm{~mm}$ by $290 \mathrm{~mm}$ cardboards with sticky upper surface, yellow or blue in colour. The blue sticky traps we used are especially aimed to attract thrips species on Saintpaulia and Frankliniella occidentalis, while the yellow colour is expected to attract all other flying insects. Also the sticky glue of the traps lures certain insects (Catch-it ${ }^{\mathrm{TM}}$, Silva miljö AB, Knäred, Sweden, http://www.silvandersson.se).

Traps were formed into a vertically positioned cylinder, fixed in a wooden stick at the level of carrot foliage top, being about $10 \mathrm{~cm}$ to $30 \mathrm{~cm}$ from soil surface depending on the height of foliage. Blue and yellow traps were placed in a row in alternating order, $10 \mathrm{~m}$ from each other. Traps, replaced with new ones at one-week intervals, were collected, covered with transparent plastic film and stored in a cold room before insect identification and counting.

\section{Reflectance of traps}

Spectrum of the sun and reflectance of sunlight from the traps were measured with a Macam 9910 spectrophotometer (Macam Photometrics Ltd, Livingston, Scotland) on a sunny morning between 9.30 a.m. and 10.00 a.m. in late April. Trap surfaces were at right-angle to the sun during measurements.

\section{Fields}

Research was carried out in one carrot and one grassland field in 1997, six carrot, five swede, five cabbage, three potato, two spinach, and one red beet field in 1998. In 1999 traps were tested in two carrot fields and a cabbage field, and in 2000 in two and in 2001 one carrot field, respectively. The size of the fields varied between 0.5 and 5 ha. Traps were arranged in one row, ex- 
Vol. 10 (2001): 277-284.

cept in two rows per field in 2000 and two rows per plot in 2001. The distance of the traps in row, parallel to the field edge, was 10 meters in each plot. The trap row was placed on the side of field, which was on the potential entering direction of the bugs. Usually traps were on the side that was closest to the forest.

In 1997 two blue and two yellow traps per field per week were used in carrot and one blue and one yellow trap on grassland for four weeks. In 1998 several crop plants were studied using three blue and four yellow traps per field for eight weeks. In 1999 three blue and three yellow traps per week were used in carrot for seven weeks. In 20006 blue and 6 yellow traps in two rows were used in both localities (Jokioinen 3.5 ha field and Kokemäki, 0.4 ha field) for nine weeks, and the positions of traps were reversed (yellow vs. blue) each week to reduce any bias due to positional effects. In 2001 a ten week investigation was conducted on a 3.6 ha carrot field in Jokioinen with four replicate plots each having two yellow and two blue traps in $10 \mathrm{~m}$ distances from each other.

Trap catches of Lygus bugs from blue and yellow traps from 1997 to 2000 were analysed using weekly catch of each trap as a true replicate. Non parametric tests (Mann-Whitney U) were used for comparisons, since data were not normally distributed because of small number of observations. Data from replicated plot experiment in 2001 were analysed with t-test using mean plot catches. SPSS for Windows statistical package was used for analyses.

\section{Results}

Reflectances from yellow and blue traps were $25 \%$ and $12 \%$, respectively, of the irradiation from the sun (Fig. 1) in the integrated wavelengths 280-700 nm (UV-radiation and photosynthetically active visible light (PAR)). Blue traps reflected from blue to red light the peak being at blue $(460 \mathrm{~nm})$. Yellow traps had a great-

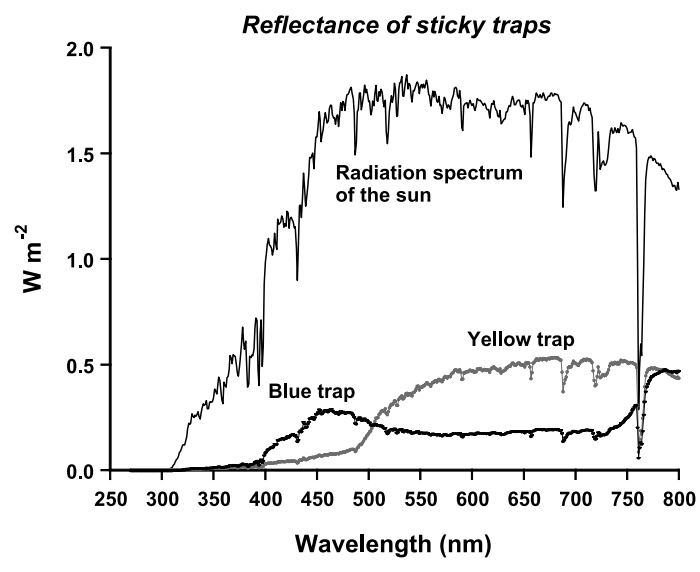

Fig. 1. Radiation $\left(\mathrm{W} / \mathrm{m}^{2}\right)$ spectrum of the sun and reflectances of yellow and blue sticky traps in UV area (250$400 \mathrm{~nm})$ and visible light area (400-750 nm).

er overall reflectance than blue traps reflecting mainly wavelengths from yellowish green (550 $\mathrm{nm})$ to red $(750 \mathrm{~nm})$ the peak being at $665 \mathrm{~nm}$. Reflectance in the UV-radiation area $(<400 \mathrm{~nm})$ was very low in both trap types.

The dominant Lygus species in trap catches was L. rugulipennis (Popp.) in most crops. L. kalmi (L.), which is a specialist feeding on Apiaceae (Linnavuori 1966), was found in carrot fields in 1999 and 2000. In 1997, in the carrot field, weekly mean catch of L. rugulipennis in blue traps $3.75 \pm 1.13$ (SE) was significantly ( $\mathrm{n}=8$, Mann-Whitney $\mathrm{U}=1, \mathrm{P}<0.001$ ) higher than in yellow traps $0.13 \pm 0.12$. The accumulated total catch in blue traps during the monitoring period was 29-times compared to yellow traps (Fig. 2a). In the grassland fields, in 1997, weekly mean catch of $L$. rugulipennis in blue traps $3.25 \pm 2.00$ was only marginally $(n=4$, $\mathrm{U}=2.5, \mathrm{P}=0.089$ ) higher than in yellow traps, $0.25 \pm 0.30$ individuals. In 1998 , the total catch of L. rugulipennis (and possibly the density also) in different field crops was so random and low that statistical significant differences were not found (Table 1).

In 1999, blue traps in carrot caught weekly $2.29 \pm 0.71$ individuals. The catch was significantly ( $\mathrm{n}=48, \mathrm{U}=848, \mathrm{P}=0.004)$ higher than 
Holopainen, J.K. et al. Lygus spp. monitoring with blue sticky traps

Table 1. Weekly numbers of Lygus rugulipennis per trap in yellow and blue traps ( $\mathrm{n}$ is same for both colors) in different field crops (21 fields) in 1998.

\begin{tabular}{lccccc}
\hline Plant species & \multicolumn{1}{c}{$\begin{array}{c}\text { Yellow } \\
\text { Mean(SE) }\end{array}$} & $\begin{array}{c}\text { Blue } \\
\text { Mean(SE) }\end{array}$ & $\mathrm{U}$ & $\mathrm{P}$ \\
\hline Carrot & $\mathrm{n}$ & $0.32(0.07)$ & $0.46(0.12)$ & 1292 & 0.676 \\
Cabbage & 52 & $0.13(0.03)$ & $0.27(0.05)$ & 270 & 0.308 \\
Potato & 25 & $0.61(0.19)$ & $0.61(0.21)$ & 160.5 & 0.960 \\
Spinach & 18 & $0.22(0.12)$ & $0.11(0.05)$ & 68 & 0.781 \\
Swede & 12 & $0.13(0.05)$ & $0.12(0.03)$ & 412 & 0.700 \\
Red beet & 30 & $0.17(0.17)$ & $0.06(0.07)$ & 17.5 & 0.902 \\
\hline
\end{tabular}
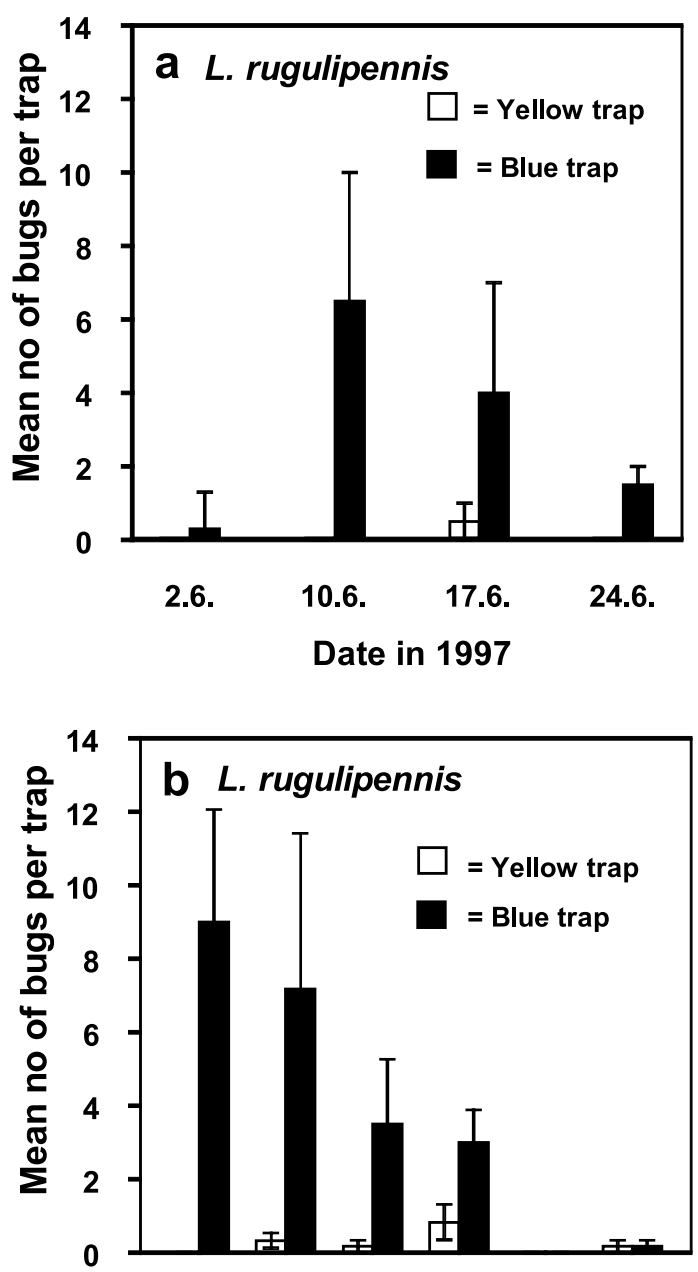

23.5. 30.5. 6.6. 13.6. 20.6. 27.6.

\section{Date in 1999}

Fig. 2. Mean weekly catch ( $\pm \mathrm{SE})$ of L. rugulipennis in carrot fields in Jokioinen in $1997(\mathrm{n}=2)$ (a) and 1999 $(n=3)(b)$. in yellow traps $(0.19 \pm 0.01)$ (Fig. $2 b)$. In the growing season of 2000, bug densities were low. The mean catch of $L$. rugulipennis in blue traps $(0.85 \pm 0.40)$ was not significantly $(\mathrm{n}=48$, $\mathrm{U}=1075, \mathrm{P}=0.503)$ higher than in yellow traps $(0.44 \pm 0.13)$. However, during peak density on June 26 significantly $(\mathrm{n}=6, \mathrm{U}=6, \mathrm{P}=0.049)$ more $L$. rugulipennis adults were caught in blue $(3.00 \pm 0.82)$ than in yellow $(1.00 \pm 0.37)$ traps (Fig. 3a). In 2001, in the replicated plot experiment mean plot catches of blue traps were significantly higher $(\mathrm{P}<0.05$, t-test $)$ than that of yellow traps on May 22 and June 5 and 12 (Fig. 4). When log-transformed numbers were used in the analyses, L. rugulipennis catches were significantly higher in blue traps also on May 22.

In carrot fields, in 1999, after the flying period of L. rugulipennis, during three weeks in July, L. kalmi was caught in traps. Numbers in yellow traps $(n=9,6.4 \pm 2.8)$ did not differ $(\mathrm{U}=33.5, \mathrm{P}=0.531)$ from catch in blue traps $(6.0 \pm 4.8)$. In 2000, L. kalmi also appeared in carrot fields in Jokioinen. The first observations were earlier than in previous year (Fig. 3b). Again the mean catch between blue $(0.31 \pm 0.13)$ and yellow $(0.58 \pm 0.17)$ traps did not differ ( $\mathrm{n}=48, \mathrm{U}=1037, \mathrm{P}=0.254$ ). In 2001 only very few L. kalmi individuals appeared in the traps not allowing any statistical analyses. 
Vol. 10 (2001): 277-284.

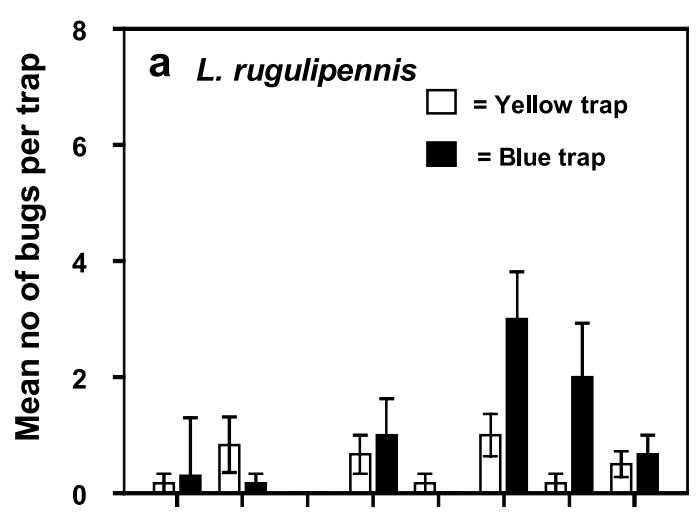

22.5. 29.5. 5.6. 12.6. 19.6. 26.6. 10.7. 17.7.

Date in 2000

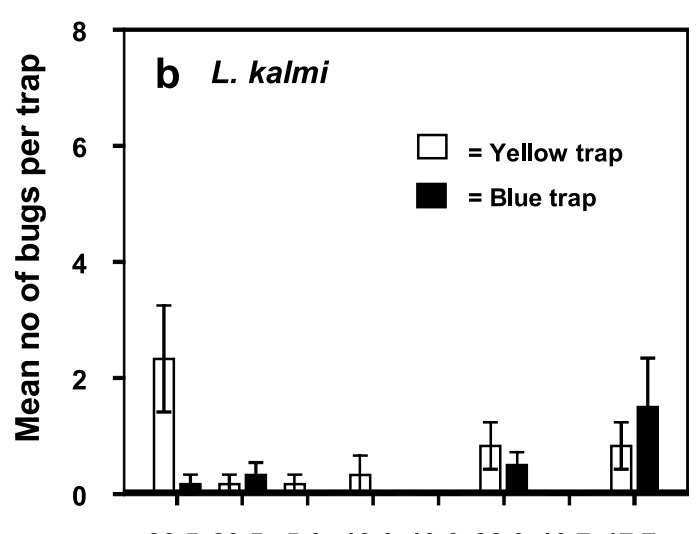

22.5. 29.5. 5.6. 12.6. 19.6. 26.6. 10.7.17.7.

\section{Date in $\mathbf{2 0 0 0}$}

Fig. 3. Mean weekly catch ( \pm SE) of L. rugulipennis (a) and L. kalmi (b) in carrot fields in Jokioinen in $2000(\mathrm{n}=6)$.

\section{Discussion}

In the years when L. rugulipennis population densities are high enough to cause extensive damage to cultivated plants, yellow traps do not indicate bug densities efficiently (Holopainen and Rikala 1990). Our replicated plot experiment in 2001 with reasonable high L. rugulipennis density confirmed the preliminary trap-based observations in the years from 1997 to 2000 that blue sticky traps caught significantly more $L$. rugulipennis than yellow traps. Therefore, blue sticky traps are suitable for monitoring of $L$. rugulipennis. However, L. kalmi was collected in equal numbers in yellow as in blue traps. This suggests that different Lygus species have a different visual response in orientation to host plants. A North American species, L. lineolaris has been observed to prefer yellow sticky traps to bright blue traps (Prokopy et al. 1979) and yellow water-pans traps to red and green traps (Landis and Fox 1972).

The variation of colour detection among insect families is poorly known, but e.g. some Heteroptera species do not perceive orange colours (Hénaut et al. 1999). Blue sticky traps have been observed to be efficient in the monitoring of some thrips species in greenhouses (Gillespie and Vernon 1990). In natural ecosystems Thysanoptera is the only insect order that is more efficiently caught by blue than yellow traps (Ho-
Fig. 4. Mean weekly catch $( \pm \mathrm{SE})$ of L. rugulipennis per trap using plot means in carrot fields in Jokioinen in $2001(n=4)$. Asterisks above blue trap catches indicate significant $(\mathrm{P}<0.05)$ difference from yellow trap catches. (o indicate $\mathrm{P}=0.067$ ).

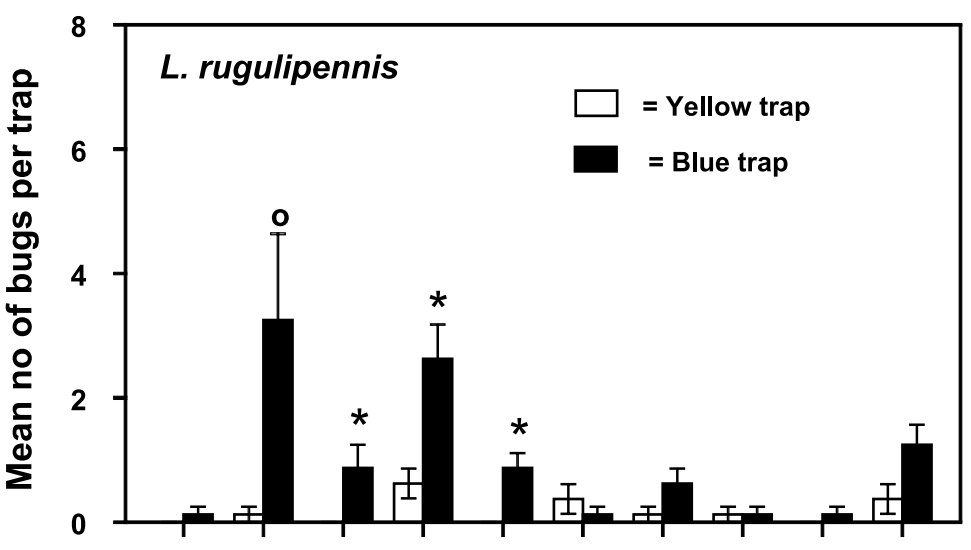

15.5. 22.5. 29.5. 5.6. 12.6. 19.6. 26.7. 3.7. 10.7. 17.7. Date in 2001 
Holopainen, J.K. et al. Lygus spp. monitoring with blue sticky traps

back et al. 1999). Hoback et al. (1999) demonstrated that attractiveness of blue and yellow traps could be variable inside one insect genus as in Frankliniella spp. thrips. Our reflectance analysis demonstrated that blue traps are more efficiently reflecting short blue light waves (400$500 \mathrm{~nm})$ than yellow traps, which are more efficiently reflecting in the green area $(500-560 \mathrm{~nm})$. This might be one explanation for the higher catch of blue traps for L. rugulipennis, since this species is not an absolute herbivore. The omnivorous diet could include insect eggs and larvae (Varis 1972), and possibly green colour of the plant foliage is not as attractive to this species as to other species in the genus Lygus. It is interesting to note, that Frankliniella occidentalis is also an omnivore (Agrawal et al. 1999) and is also trapped in greater numbers on blue traps than on yellow (Gillespie and Vernon 1990).

Colour preference of Lygus bugs might be different also in different crop types. Prokopy et al. (1979) found that for L. lineolaris that damage flowers in apple trees, bright blue sticky traps were not as attractive as non-ultraviolet-light reflecting white, yellow or plexiglas rectangles, hung vertically at about $0.7 \mathrm{~m}$ above ground. We did not find yellow traps to catch $L$. rugulipennis more efficiently than blue traps in any of the studied fields.

Blue traps are probably most effective for Lygus monitoring on crops where they damage plants on seedling stage, and the foliage of young plants do not shade the soil surface e.g. carrot, conifer seedlings, transplanted cabbage seed- lings. Kostal and Finch (1996) found that the cabbage root fly Delia radicum (L.), avoided landing on blue traps when background was green, while brown background resulted in the relative increase of catches in the non-preferred violet and blue traps.

Prokopy and Owens (1978) and Prokopy et al. (1979) found that white sticky traps were more efficient than yellow sticky traps to collect $L$. lineolaris. Therefore efficiency of white sticky traps to collect L. rugulipennis should be tested and compared to blue sticky traps. However, at the moment blue traps are significantly more efficient than yellow traps for L. rugulipennis monitoring.

Since L. rugulipennis frequently damage the apical meristem in the production of vegetable seedlings during spring in greenhouses, in addition to the thrips monitoring, the use of blue traps for timing of chemical control of Lygus bugs is recommendable. The blue sticky traps seem also to be suitable monitoring tool for the forecast system of L. rugulipennis that is under development in MTT Agrifood Research Finland. Vegetable growers make observations and countings of bug densities in their fields and send the information by the short message service of their mobile phones to the central database of MTT. As a feedback the growers receive on the display screen of they mobile phone the latest forecast of bug densities in their area.

Acknowledgements. We want to thank Outi Järvinen for insect counting and identification and Timo Oksanen for the help in reflectance measurements. 


\section{References}

Agrawal, A.A., Kobayashi, C. \& Thaler, J.S. 1999. Influence of prey availability and induced host-plant resistance on omnivory by western flower thrips. Ecology 80: 518-523.

Fleischer, S.J., Gaylor, M.J. \& Hue, N.V. 1988. Dispersal of Lygus lineolaris (Heteroptera: Midridae) adults through cotton following nursery host destruction. Environmental Entomology 17: 533-541.

Fye, R.E. 1984. Damage to vegetable and forage seedlings by overwintering Lygus hesperus (Heteroptera: Miridae) adults. Journal of Economic Entomology 77: 1141-1143.

Gillespie, D.R. \& Vernon, R.S. 1990. Trap catch of western flower thrips (Thysanoptera: Thripidae) as affected by color and height of sticky traps in mature greenhouse cucumber crops. Journal of Economic Entomology 83: 971-975.

Hénaut, Y., Alauzet, C., Dargagnon, D. \& Lambin, M. 1999. Visual learning in larval Orius majusculus a polyphagous predator. Entomologia experimentalis et Applicata 90: 103-107.

Hoback, W.W., Svatos, T.M., Spomer, S.M. \& Higley, L.G. 1999. Trap color and placement affects estimates of insect family-level abundance and diversity in a $\mathrm{Ne}$ braska salt marsh. Entomologia Experimentalis et Applicata 91: 393-402.

Holopainen, J.K. 1986. Damage caused by Lygus rugulipennis Popp. (Heteroptera, Miridae), to Pinus sylvestris L. seedlings. Scandinavian Journal of Forest Research 1: 343-349.

- \& Rikala, R. 1990. Abundance and control of Lygus rugulipennis (Heteroptera: Miridae) on Scots pine ( $\mathrm{Pi}$ nus sylvestris L.) nursery stock. New Forests 4: 1325.

- \& Rikala, R.1991. Luteet ja männyn taimien kasvuhäiriöt. Summary: Lygus bugs and growth disturbances in Scots pine seedlings. Metsäntutkimuslaitoksen tiedonantoja 379. p. 1-35.

- \& Varis, A.-L. 1991. Host plants of the European tarnished plant bug Lygus rugulipennis Popp. (Heteroptera: Miridae). Journal of Applied Entomology 111: 484-498.
Johnson, M.P. \& Mueller, A.J. 1988. Three-cornered alfalfa hopper response to six sticky trap colors. South western Entomologist 13: 101-105.

Kostal, V. \& Finch, S. 1996. Preference of the cabbage root fly Delia radicum (L.), for coloured traps: influence of sex and physiological status of the flies, trap background and experimental design. Physiological Entomology 21: 123-130.

Landis, B.J. \& Fox, L. 1972. Lygus bugs in eastern Washington: color preferences and winter activity. Environmental-Entomology 1: 464-465.

Linnavuori, R. 1966. Nivelkärsäiset I. Hemiptera I. Luteet I: Amohibicoriomorpha ja Geocorisidae I: Miridae. Suomen Eläimet - Animalia Fennica 10: 1-205.

Prokopy, R.J. \& Owens, E.D. 1978. Visual generalists with visual specialist phytophagous insects: host selection behaviour and application to management. Entomologia Experimentalis et Applicata 24: 409-420.

- \& Owens, E.D. 1983. Visual detection of plants by herbivorous insects. Annual Review of Entomology 28: 337-364.

-, Adams, R.G. \& Hauschild, K.I. 1979. Visual responses of tarnished plant bug adults on apple. Environmental Entomology 8: 202-205.

Schowalter, T.D. \& Stein, J.D. 1987. Influence of Douglas-fir seedling provenance and proximity to insect population sources on susceptibility to Lygus hesperus (Heteroptera: Miridae) in a forest nursery in western Oregon. Environmental Entomology 16: 984-986.

Slaymaker, P.H. \& Tugwell, N.P. 1984. Inexpensive femalebaited trap for the tarnished plant bug (Hemiptera: Miridae). Journal of Economic Entomology 77: 10621063.

Young, O.P. 1986. Host plants of the tarnished plant bug, Lygus lineolaris (Heteroptera: Miridae). Annals of Entomological Society America 79: 747-762.

Varis, A.-L. 1995. Species composition, abundance, and forecasting of Lygus bugs (Heteroptera: Miridae) on field crops in Finland. Journal of Economic Entomology 88: 855-858.

- $\quad$ 1972. The biology of Lygus rugulipennis Popp. (Het. Miridae) and the damage caused by this species to sugar beet. Annales Agriculturae Fenniae 11: 1-56. 


\title{
AGRICULTURAL AND FOOD SCIENCE IN FINLAND
}

Holopainen, J.K. et al. Lygus spp. monitoring with blue sticky traps

\section{SELOSTUS}

\section{Siniset liimapyydykset ovat keltaisia liimapyydyksiä tehokkaampia peltoluteen tarkkailussa}

\author{
Jarmo K. Holopainen, Sakari Raiskio, Anu Wulff ja Kari Tiilikkala \\ MTT (Maa- ja elintarviketalouden tutkimuskeskus) ja Kuopion yliopisto
}

Lygus-suvun luteet (Heteroptera, Miridae) ovat useiden viljelykasvien merkittäviä tuholaisia. Luteiden tarkkailua ja ennustemenetelmien kehittämistä on haitannut luteiden vähäinen hakeutuminen keltaisiin liimapyydyksiin. Määritimme keltaisista liimapyydyksistä ja ripsiäisten tarkkailuun kehitetyistä sinisistä liimapyydyksistä auringon valon kokonaisheijastumisen, ja vertailimme pyydysten ludesaaliita viitenä peräkkäisenä kasvukautena pääasiassa porkkanakasvustossa. Lisähavaintoja kerättiin nurmelta, kaalilta, perunalta, pinaatilta, lantulta ja punajuurik- kaalta. Porkkanalla siniset liimapyydykset pyydystivät selvästi tehokkaammin peltoludetta Lygus rugulipennis (Popp.) kuin keltaiset liimapyydykset. Harvinaisemmalle, mutta porkkanapelloille tyypilliselle Lygus kalmi (L.) -ludelajille siniset ja keltaiset pyydykset osoittautuivat yhtä houkutteleviksi. Tulokset osoittavat, että siniset liimapyydykset sopivat peltoluteen tarkkailuun ja niiden avulla voidaan osoittaa luteiden saapuminen kasvustoon etenkin vuosina, jolloin luteet esiintyvät runsaslukuisina. 